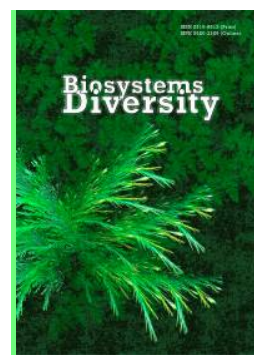

\title{
Co-infection of Trichuris vulpis and Toxocara canis in different aged dogs: Influence on the haematological indices
}

\author{
I. V. Saichenko*, A. A. Antipov*, T. I. Bakhur*, L. V. Bezditko**, S. S. Shmayun* \\ *Bila Tserkva National Agrarian University, Bila Tserkva, Ukraine \\ **Polissia National University, Zhytomyr, Ukraine
}

\section{Article info \\ Received 24.04.2021 \\ Received in revised form 19.05 .2021 \\ Accepted 20.05.2021}

Bila Tserkva National Agrarian University Soborna sq., $8 / 1$ Bila Tserkva, 09117,

Utraine

Tel.: +38-098-305-78-13

E-mail:fly_13@ukr.net

Polissia National

University, Staryi blvd., 7

Zhytomyr, 10008, Ukraine.

$\mathrm{Tel} \cdot+38-096-982-47-94$

E-mail:bezditkon@ukr.net

Saichenko, I. V., Antipov, A. A., Bakhur, T. I., Bezditko, L. V., \& Shmayun, S. S. (2021). Co-infection of Trichuris vulpis and Toxocara canis in different aged dogs: Influence on the haematological indices. Biosystems Diversity, 29(2), 129-134. doi:10.15421/012117

Trichuris vulpis and Toxocara canis are worldwide parasitic nematodes affecting dogs and mammals of the Canine family. Due to the special structure of the shells, the eggs of these geohelminths can maintain their viability in soil, sand, water and the environment for a long time. The study involved young (6-12 months old) and adult (1.5-8.0 years old) dogs affected by co-infection of $T$. vulpis $+T$. canis; the control group consisted of dewormed healthy animals of the same age. Parasitological examination of dogs' faeces was performed using a "Counting Chamber for Ovoscopic Researches"; morphological parameters, indicators of nutrient metabolism, mineral metabolism and activity of enzymatic systems were determined in blood and serum. According to the results of parasitological research on the dogs, it was found that young animals are more prone to toxocarosis, and adults - trichurosis. The co-infection of nematodes T. vulpis + T. canis in dogs develops several changes in haematological parameters: a significant decrease in erythrocytes, haemoglobin, $\mathrm{MCV}, \mathrm{MCH}$, and haematocrit, leukocytosis with basophils and eosinophilia in young infected animals; and eosinophilia and basophilia (15.9 times) in adults, compared with healthy dogs of the same age. Among the changes in serum biochemical parameters, young infected dogs showed a decrease in the concentration of total protein and albumin content, an increase in the content of "acute phase" proteins ( $\alpha-1, \alpha-2$ and $\beta$-globulins), an increase in cholesterol and total bilirubin; in adult infected dogs, a decrease in albumin content, an increase in the content of $\alpha-1, \alpha-2$, and $\beta$-globulins, an increase in the concentration of cholesterol and total bilirubin, a decrease in the concentration of urea in comparison with healthy animals were determined. Also, among the indicators of mineral metabolism, a decrease in the concentration of calcium and magnesium in the serum was found in young infected dogs. Among the changes in the enzyme metabolism in the serum of infected dogs, there was an increase in the activity of all studied enzymes in animals of both research groups: ALT, AST, $\alpha$-amylase, GGT and ALP. Thus, co-infection with nematodes $T$. vulpis $+T$. canis has a complex pathogenic effect on the body of dogs of all ages, which manifested itself in multiple changes in haematological parameters. In the future, the authors' team plan to develop comprehensive measures to combat nematode infections in different living conditions of dogs, taking into account the results of the current research.

Keywords: Nematoda; Trichuridae; Ascarididae; parasites; canine; blood parameters.

\section{Introduction}

Trichuris vulpis (Froelich, 1789) and Toxocara canis (Werner, 1782) are parasitic nematodes, the definitive hosts of which are dogs and members of the Canine family. Both parasites are geohelminths, their eggs mature in the environment, maintaining viability for a long time due to the special structure of the shells (Abou-El-Naga, 2018; Bojar \& Klapec, 2018; Borodai \& Hodyna, 2019; Marko et al., 2020; Ristic et al., 2020). According to the results of scientific research, the geography of biohelminth distribution centres is usually more extensive, even despite the binding of intermediate nutrients to certain living conditions (Boyko \& Brygadyrenko, 2017; Zazharska et al., 2018; Feshchenko et al., 2019). At the same time, the areas of geohelminths distribution are more limited, tied to the distribution and concentration of susceptible definitive hosts (Melnychuk et al., 2020). Recent publications indicate a significant prevalence of T. canis and T. vulpis nematodes among domestic and stray dogs in the United States, Argentina, Mexico, Ethiopia, Italy, Serbia, Bulgaria, Iran, Uzbekistan, and wild wolves in Germany. Thus, according to the results of the study of dog faeces and soil samples collected in the Central Park of Oklahoma, parasites were found in $24 \%$ of samples, while $6.1 \%$ of samples were co-infected. Eggs and oocysts of parasites Ancylostoma spp. (14.5\%), T. vulpis (6.7\%), Cystoisospora spp. (3.6\%), Sarcocystis spp. (1.7\%), and Giardia duodenalis (1.4\%) were found. Only a small number of test samples contained T. canis eggs (Duncan et al., 2020). According to a study of faecal samples from domestic dogs conducted in the urban area of Cordoba (Argentina), the overall prevalence of parasites in the gastrointestinal tract was $45.2 \%$, among them Ancylostoma caninum (30.8\%), T. vulpis (9.9\%), Cystoisospora spp. (7.7\%), T. canis (6.9\%), and Giardia spp. (5.9\%). There was also an increased risk of infection associated with age for T. canis, Cystoisospora spp., and Giardia spp. (Motta et al., 2019). Researchers on the zoonotic agents' prevalence in Merida (Yucatan, Mexico) found that $11.0 \%$ of faecal samples collected from city's public parks tested positive for intestinal nematode eggs. Eggs of three species of nematodes were found: Ancylostoma caninum (10.0\%), T. canis $(10.0 \%)$, and T. vulpis $(1.0 \%)$. In addition, most positive samples contained eggs of only one parasite ( $10.0 \%$ of all tested) (Medina-Pinto et al., 2018). A mass study of dog faeces conducted in three cities in the West Shoa Zone (Ethiopia) showed that the prevalence of helminthic infestations was $51.0 \%$. As a result, eggs of Ancylostoma caninum (36.8\%), T. canis $(9.7 \%)$, Uncinaria spp. (4.5\%), Physaloptera canis (4.5\%), Salminicola canis (3.2\%), Oncicola canis (1.9\%), Spirocerca lupi (0.3\%), Toxascaris leonina (1.0\%), T. vulpis (1.0\%), Diphyllobothrium spp. (1.3\%), Taenidae spp. (0.3\%), and Mesocestoides spp. (0.3\%) were found (Gebremedhin et al., 2020).

Significantly higher rates of $T$. vulpis prevalence were found in European countries. Thus, examining faecal samples from domestic dogs in Italy, the researchers found that $9.7 \%$ of the samples were positive for at least one species of parasite. Detected pathogens of helminthoses were T. vulpis (5.5\%), T. canis (4.3\%), Ancylostoma spp. (0.6\%), Eucoleus aerophilus $(0.4 \%)$, and no causative agents of cestodes were detected (La Torre et al., 2018). The high prevalence of $T$. vulpis is also confirmed by the results of large-scale studies of faecal samples from domestic and 
dogs from a shelter in the Lazio Region (Central Italy). Researchers have identified pathogens such as Giardia duodenalis, Cystoisospora sp., Ancylostomatidae, T. canis, Toxascaris leonina, T. vulpis, Eucoleus bohmi, Eucoleus aerophilus, Mesocestoides sp., Taeniidae, and Dipylidium caninum. The overall prevalence of helminths was $29.1 \%$, and the prevalence of T. vulpis $-9.9 \%$ (the highest rate among all pathogens) (Scaramozzino et al., 2018). The prevalence rates of $T$. canis and $T$. vulpis were slightly lower among the population of wild European wolves in Lower Saxony (Germany). Overall, $60.9 \%$ of the faecal samples were positive for at least one of the seven helminth egg types. These parasites were Capillaria / Eucoleus spp. (31.9\%), Taeniidae (21.7\%), Ancylostomatidae (20.3\%), Alaria alata (16.0\%), T. canis (13.0\%), as well as Toxascaris leonina and T. vulpis (5.8\% each) (Bindke et al., 2019). Parasitologists from Serbia examined soil and sand samples in public gardens and playgrounds in Nis town. It was found that $38-46 \%$ of soil samples and $40 \%$ of sand were contaminated with pathogens of seven parasitic diseases. Medium-high degree of contamination with $T$. canis eggs (14-22\%) and low-medium Ancylostoma spp. degree of contamination was detected in soil samples (4-12\%). T. canis (26\%) and Alaria alata (16\%) eggs contamination was found in the sand samples (Ristic et al., 2020). According to the results of testing faecal samples of dogs kept by owners outside their homes in Bulgaria, the overall prevalence of parasites in the gastrointestinal tract was $64.5 \%$. Strongylates became the most widespread among dogs ( $\mathrm{An}$ cylostoma sp. and Uncinaria sp.) $-54.1 \%$, lower rates were characteristic of T. vulpis (15.1\%), Capillaria sp. (11.0\%), T. canis (6.4\%), Cystoisospora sp. (4.1\%), Sarcocystis sp. (2.3\%), Toxascaris leonina (1.7\%), Taenia sp. (1.2\%), and Linguatula serrata (0.6\%) (Iliev et al., 2020).

The results of testing faecal samples in Kermanshah Province (Iran) showed that $76.4 \%$ of dogs were infected with parasitic pathogens of the gastrointestinal tract. The prevalence of pathogens among domestic and stray dogs was: Toxascaris leonina $(20.8 \%$ and $27.6 \%)$, T. canis $(7.5 \%$ and $9.4 \%)$, Taenia spp. (9.2\% and 9.4\%), hookworm spp. (18.3\% and $33.7 \%$ ), Capillaria spp. (0.8\% and 1.7\%), Dicrocoelium dendriticum ( $0.8 \%$ and $3.3 \%)$, Fasciola spp. ( $0.8 \%$ and $2.2 \%$ ), Acanthocephala spp. (3.3\% and 5.5\%), T. vulpis (0.8\% and $1.7 \%)$, Dipylidium caninum $(4.2 \%$ and 3.3\%), Physaloptera spp. (6.7\% and 6.6\%), Cryptosporidium spp. (21.7\% and 25.4\%), Eimeria spp. (35.0\% and 34.3\%), Giardia spp. $(6.7 \%$ and 12.7\%), Cystoisospora spp. (7.5\% and 5.5\%), Blastocystis spp. (18.3\% and 20.4\%), and Sarcocystis spp. (6.7\% and 7.2\%), respectively (Mohaghegh et al., 2018). Parasitological studies in the Samarkand region (Uzbekistan) showed that T. canis and T. vulpis co-infected with Taenia hydatigena, Dipylidium caninum, Diplopylidium nolleri, Mesocestoides lineatus, were found among $1.0 \%$ of the studied dogs (Yong et al., 2019).

Regarding the distribution of $T$. canis and $T$. vulpis among dogs in Ukraine, Yevstafieva et al. (2020) indicate that these nematodes are frequent co-infections with ectoparasites Ctenocephalides spp. In various combinations of other parasite species, T. canis was found in combination with Ctenocephalides felis in $7.8 \%$ of the studied cases $(\mathrm{n}=3171)$ and with C. canis in $7.2 \%$ of cases; $T$. vulpis - in $7.4 \%$ and $8.3 \%$, respectively (Yevstafieva et al., 2020). A study of the T. vulpis prevalence in Poltava city showed that the overall prevalence of this parasite was $25.9 \%$. Trichurosis was found to develop as a mono-infection in $53.6 \%$ of cases and as a co-infection in $46.4 \%$. Co-parasitization of T. canis and T. vulpis was found in $15.4 \%$ of co-infections (Borodai \& Hodyna, 2019). Prevalence (in the form of mono-invasions) was found among dogs of the Kyiv region: T. vulpis $-27.1 \%$ of all studied animals, and T. canis $-6.6 \%$. The combination of both nematodes in the form of double co-infection was found in $1.9 \%$ of animals (Saichenko \& Antipov, 2020). According to the results of the study of soil samples taken at the cynological centre in Kharkiv region, it was found that $6.1 \%$ of samples were contaminated with $T$. canis eggs and $20.6 \%$ of samples - with T. vulpis eggs (Paliy et al., 2018).

Scientific publications demonstrate results of studies of haematological parameters of dogs infected with various co-infections of parasites, including the gastrointestinal (Schmidt et al., 2016; Rouf et al., 2017; Kumar, 2021). However, data and analysis of changes in haematological parameters in co-infection with $T$. vulpis $+T$. canis, as an important aspect of studying the pathogenesis of infection, have not been described. Therefore, the current study aimed to study the intensity of infection of members of the co-infection of $T$. vulpis $+T$. canis, depending on the age of the feeders, as well as to establish changes in haematological parameters of dogs with such infection with age. Such data will further facilitate the development of complex measures to combat nematode infections in different living conditions of dogs.

\section{Materials and methods}

The study was conducted in 2020 at the Homeless Animal Welfare Centre "In Good Hands" (Vyshneve town, Kyiv region), on the basis of the Scientific Research Institute of Internal Diseases of Animals and Laboratory of Department of Parasitology and Pharmacology, Bila Tserkva National Agrarian University. The research protocol of the current study was approved by the Ethics Committee of the Bila Tserkva National Agrarian University (Approval number: 21.05.2020 / No. 7, conclusion 3/1).

Six weeks before the start of the study, we selected 25 young dogs aged 6-12 months and 20 adult dogs aged $1.5-8.0$ years, spontaneously infected with $T$. canis and $T$. vulpis nematodes for inclusion in the study groups. At another site of the shelter, 20 and 10 animals were selected, respectively, and dewormed for further inclusion in control groups. Additionally, the enclosures of animals of this group were disinfected to prevent re-infection of dogs. The dogs of the experimental and control groups belonged to the German Shepherd, Labrador Retriever, Russian Spaniel, and Belgian Shepherd breeds and their crossbreeds. Animals of all groups were of both sexes and sterilized. At the end of the study, all dogs in the experimental groups underwent treatment for nematodes.

Infection of dogs with nematode agents before and during the study was established using the "Counting Chamber for Ovoscopic Research". To do this, $1 \mathrm{~g}$ of faeces from the average sample was mixed with a flotation solution of granular ammonium nitrate (solution density - $1300 \mathrm{~g} / \mathrm{L}$ ), stirring and bringing the volume to $30 \mathrm{~mL}$. The resulting suspension was filtered through a metal sieve. To start working with the chamber, on its base, with the help of two pins, cover glass was fixed with the grating down. Using a pipette, the resulting suspension in a volume of $2 \mathrm{~mL}$ was introduced into one of the cells through the recess of the chamber base. The cell was considered filled when the suspension completely expelled air from under the cover glass. Thus, the surface of the suspension was in the same plane as the grid applied to the cover glass. Ovoscopy was performed 3 minutes after filling the cell (this time is required for flotation of eggs, as a result of which they are placed on the surface, in the same plane with the camera grid). In the field of view of the biological light microscope "Biomed +" XSM-20 ("BioMed", China) at $4 \times 10$ we found a grid that serves as a guide for counting helminth eggs. After counting helminth eggs, their number was multiplied by 15 and a number obtained that was taken as the number of eggs in $1 \mathrm{~g}$ of faeces of the test animal.

The intensity of nematode infection in a particular animal was considered the average number of parasite eggs in $1 \mathrm{~g}$ of its faeces according to the results of three trials. According to the results of parasitological research, the group of young dogs was characterized by average infection rates of $29.28 \pm 3.76 T$. canis eggs per $1 \mathrm{~g}$ of faeces and $5.5 \pm 0.67$ T. vulpis eggs per $1 \mathrm{~g}$ of faeces (Fig. 1). For animals of the adult dogs' group, these values were $11.35 \pm 3.29$ and $29.55 \pm 7.67$ eggs per $1 \mathrm{~g}$ of faeces, respectively (Fig. 2).

Blood samples from dogs of all groups were performed in the morning before feeding from the Vena cephalica antebrachii. Blood samples were taken in vacuum tubes $10 \mathrm{~mL}$ volume (Vacutest, Italy). An anticoagulant ethylenediaminetetraacetic acid (EDTA) was used. In the dogs' blood, the total number of erythrocytes, haemoglobin content, haematocrit, average erythrocyte volume (MCV), the content of leukocytes (including the ratio of their fractions) and platelets were determined by an automatic haematological analyzer Mythic 18 (Orphee SA, Switzerland) and reagents by PZ Cormay SA (Poland). Haemoglobin content in erythrocyte (MSN) was calculated mathematically.

Biochemical parameters of dogs' serum were determined using HTI BioChem SA Semi-Auto Chemistry Analyzer (High Technology, Inc., USA), using appropriate reagents from the same manufacturer.

The datasets were expressed as mean $(\mathrm{x}) \pm$ standard error of the mean (SE). Mathematical analysis of the study results was conducted in Statistica 13.3 IT Application (StatSoft Inc., USA). Differences between average values were considered statistically significant at $\mathrm{P}<0.05$ (ANOVA). 


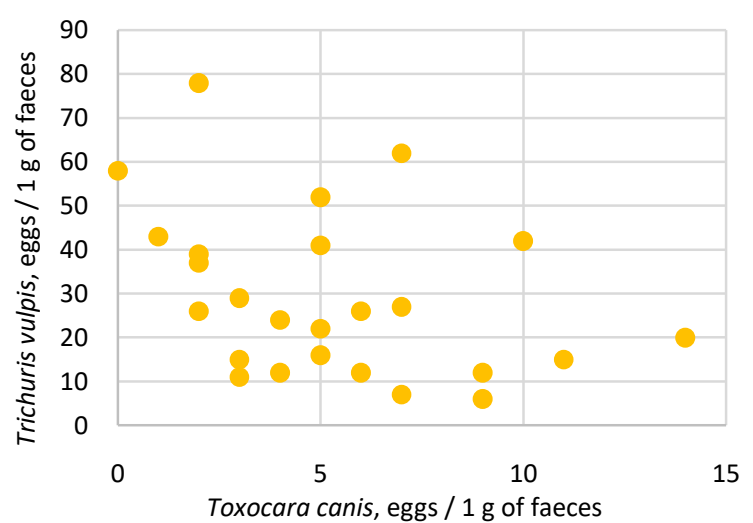

Fig. 1. The intensity of parasitic nematode infection in young dogs (6-12 months old) in the research

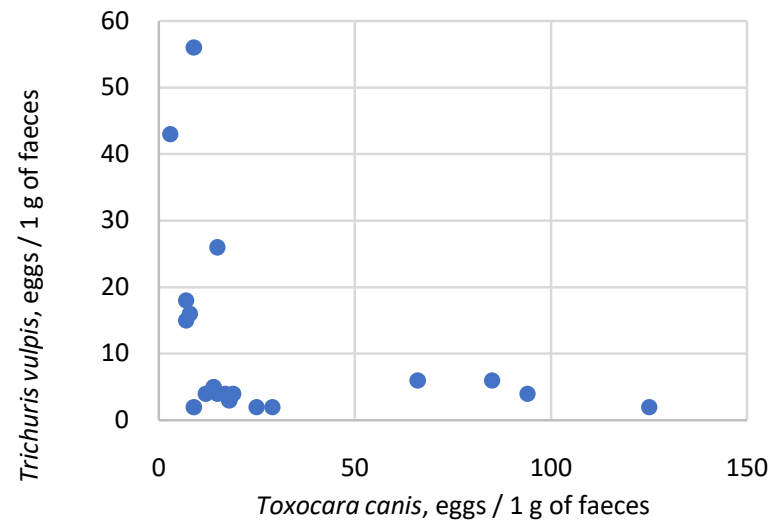

Fig. 2. The intensity of parasitic nematode infection in adult dogs (1.5- 8.0 years old) in the research

\section{Results}

According to haematological studies, co-infection of nematodes caused many significant changes in morphological parameters of blood and biochemical parameters of blood serum. In young infected animals (Table 1), a significant decrease in the number of erythrocytes (by 19.3\%) and haemoglobin concentration (by 31.2\%) was found in comparison with healthy dogs of the same age. The indicators of MCV (by 18.4\%) and MCH (by $14.5 \%$ ), haematocrit (by $46.1 \%$ ) were also reduced. Also, in the blood of young infected dogs acute leukocytosis was found (70.3\%) with the appearance of basophils and eosinophilia (9.57 times).

Haematological parameters of adult infected dogs were marked by eosinophilia (4.95 times) and basophilia (15.92 times). No significant changes in platelet counts in infected dogs of both ages were found.

Changes in the serum biochemical parameters of infected dogs were much larger than in healthy animals of the same age range (Table 2). Thus, young animals were characterized by a decrease in the concentra- tion of total protein (by 11.3\%), and in the structure of protein fractions there was a decrease in albumin content (by 19.6\%), and an increase in $\alpha-1$ (by $52.0 \%$ ), $\alpha-2$ (by $29.2 \%$ ) and $\beta$-globulins (by $44.2 \%$ ). There was also an increase in the concentration of cholesterol (by $82.5 \%$ ) and total bilirubin (by 28.8\%) in the serum of dogs in this group.

Adult infected dogs were also characterized by changes in the ratio of serum protein fractions (decrease in albumin content by $24.4 \%$, increase in $\alpha-1$ by $36.7 \%, \alpha-2$ by $25.9 \%$ and $\beta$-globulins by $45.4 \%$ ), however, without significant changes in the concentration of total protein. There was also a sharp increase in the concentration of cholesterol (2.35 times), total bilirubin (2.04 times) and a decrease in the concentration of urea (by 23.4\%) in the blood serum of animals in this group. Mean creatinine levels in dogs of both groups and urea in young animals had no significant changes, but individual values of individual animals differed significantly within the group, which was manifested in large values of standard error (SE).

Speaking of the indicators of mineral metabolism in the serum of dogs infected with co-invasion of $T$. vulpis + T. canis, no significant changes were found (Table 3 ). However, young dogs were characterized by a decrease in the concentration of calcium (by 12.8\%) and magnesium (by $11.5 \%)$ in the serum.

Examining the indicators of enzyme metabolism in the serum of infected dogs, we found an increase in the activity of all studied enzymes in animals of both experimental groups (Table 4). Thus, among young dogs the activity of ALT was increased 3.22 times, AST - 2.00 times, $\alpha$-amylase $-70.2 \%$, GGT -2.94 times, and ALP -4.24 times, compared with healthy animals of the same age. For the group of adult infected dogs, these indicators were 5.10 times higher, 4.75 times higher, $29.6 \%$ higher, 3.58 times higher, and 5.94 times higher, respectively.

Thus, co-infection was found to be predominance of parasitization by $T$. canis in young dogs and T. vulpis in adults. The results of haematological examination revealed significant deviations in infected animals of both age groups.

\section{Discussion}

Examining the prevalence of $T$. canis infection, the researchers found that this rate was significantly higher in young dogs, while there was no significant difference in the prevalence of $T$. vulpis by age (Savilla et al., 2011). Similar results were obtained by other scientists (Gebremedhin et al., 2020), who found that the probability of infection with $T$. canis is 4.5 times higher in young dogs than in adults. Motta et al. (2019) and Stafford et al. (2020), like previous authors, indicate that the age of dogs increases the risk of infection with the nematode $T$. canis and do not consider the spread of $T$. vulpis related to the age of the owner. However, some publications describe an increased risk of $T$. vulpis infection in older dogs (Symeonidou et al., 2017).

According to the results of current studies, the same distribution of both studied nematodes was found among both young and adult dogs. However, there was a clear predominance in the intensity of $T$. canis infection among dogs aged 6-12 months, and T. vulpis in adult animals. Such indicators indicate the stationary focal contamination of the territory and premises of the studied nursery with eggs of parasitic nematodes and require comprehensive measures to combat these infections.

Table 1

Changes in haematological parameters of dogs with co-infection T. vulpis + T. canis $(\mathrm{x} \pm \mathrm{SE})$

\begin{tabular}{lcccc}
\hline \multirow{2}{*}{ Indexes } & \multicolumn{2}{c}{ Young dogs (6-12 months) } & \multicolumn{2}{c}{ Adult dogs (1.5-8.0 years) } \\
\cline { 2 - 5 } & healthy, $\mathrm{n}=15$ & infected, $\mathrm{n}=25$ & healthy, $\mathrm{n}=10$ & infected, $\mathrm{n}=20$ \\
\hline Erythrocytes, $\times 10^{12} / \mathrm{L}$ & $6.46 \pm 0.39$ & $5.21 \pm 0.18^{* *}$ & $6.38 \pm 0.21$ & $6.55 \pm 0.26$ \\
Haemoglobin, $\mathrm{g} / \mathrm{L}$ & $158.9 \pm 2.8$ & $109.3 \pm 3.3^{* * *}$ & $165.2 \pm 3.6$ & $159.9 \pm 4.5$ \\
Mean corpuscular volume (MCV), $\mathrm{fL}$ & $67.6 \pm 1.7$ & $55.1 \pm 1.3^{* * *}$ & $71.2 \pm 2.0$ & $66.2 \pm 2.2$ \\
Mean content of haemoglobin (MCH), fmo/cell & $1.52 \pm 0.06$ & $1.30 \pm 0.07^{*}$ & $1.60 \pm 0.07$ & $1,51 \pm 0.06$ \\
Haematocrit, \% & $44.0 \pm 1.1$ & $23.7 \pm 0.9^{* * *}$ & $46.5 \pm 1.5$ & $47.8 \pm 0.9$ \\
Leukocytes, $\times 10^{9} / \mathrm{L}$ & $10.36 \pm 0.25$ & $17.64 \pm 0.63^{* * *}$ & $9.91 \pm 0.64$ & $9.75 \pm 0.58$ \\
Eosinophils, $\%$ & $1.94 \pm 0.07$ & $18.56 \pm 0.67^{* * *}$ & $4.26 \pm 0.18$ & $21.10 \pm 2.28^{\circ 00}$ \\
Basophils, $\%$ & 0 & $3.18 \pm 0.11$ & $0.52 \pm 0.09$ & $8.28 \pm 1.25^{\circ 00}$ \\
Platelets, $\times 10^{9} / \mathrm{L}$ & $305.3 \pm 15.9$ & $320.9 \pm 18.2$ & $289.6 \pm 13.3$ & $311.3 \pm 24.4$ \\
\hline
\end{tabular}

Note: ${ }^{*}-\mathrm{P}<0.05,{ }^{* *}-\mathrm{P}<0.01,{ }^{* * *}-\mathrm{P}<0.001$ compared to healthy young dogs; ${ }^{\circ}-\mathrm{P}<0.05,{ }^{\circ}-\mathrm{P}<0.01,{ }^{000}-\mathrm{P}<0.001$ compared to healthy adult dogs. 
Table 2

Changes in biochemical parameters of nutrient metabolism in the serum of dogs with co-infection T. vulpis + T. canis $(\mathrm{x} \pm \mathrm{SE})$

\begin{tabular}{|c|c|c|c|c|}
\hline \multirow{2}{*}{ Indexes } & \multicolumn{2}{|c|}{ Young dogs (6-12 months) } & \multicolumn{2}{|c|}{ Adult dogs (1.5- -8.0 years) } \\
\hline & healthy, $\mathrm{n}=15$ & infected, $\mathrm{n}=25$ & healthy, $\mathrm{n}=10$ & infected, $n=20$ \\
\hline Glucose, $\mathrm{mmol} / \mathrm{L}$ & $5.93 \pm 0.21$ & $5.62 \pm 0.31$ & $5.74 \pm 0.17$ & $5.81 \pm 0.28$ \\
\hline Total protein, $\mathrm{g} / \mathrm{L}$ & $62.3 \pm 1.8$ & $55.3 \pm 1.5^{* *}$ & $70.7 \pm 2.3$ & $71.7 \pm 1.5$ \\
\hline Albumin, $\%$ & $51.2 \pm 1.9$ & $41.2 \pm 1.4^{* * *}$ & $47.0 \pm 1.1$ & $35.6 \pm 1.2^{\circ 00}$ \\
\hline$\alpha-1$ globulin, $\%$ & $8.28 \pm 0.39$ & $12.59 \pm 0.73^{* * *}$ & $9.37 \pm 0.33$ & $12.81 \pm 0.56^{\circ 00}$ \\
\hline$\alpha-2$ globulin, $\%$ & $8.57 \pm 0.46$ & $11.07 \pm 0.31 * * *$ & $8.45 \pm 0.56$ & $10.64 \pm 0.27^{\circ 0}$ \\
\hline$\beta$-globulin, $\%$ & $9.62 \pm 0.32$ & $13.87 \pm 0.60^{* * *}$ & $10.02 \pm 0.26$ & $14.57 \pm 0.35^{\circ 00}$ \\
\hline$\gamma$ globulin, $\%$ & $22.31 \pm 0.88$ & $21.30 \pm 0.79$ & $25.14 \pm 0.67$ & $26.42 \pm 1.05$ \\
\hline Creatinine, $\mu \mathrm{mol} / \mathrm{L}$ & $84.2 \pm 3.4$ & $92.2 \pm 4.8$ & $90.7 \pm 2.7$ & $86.8 \pm 5.7$ \\
\hline Urea, $\mathrm{mmol} / \mathrm{L}$ & $6.70 \pm 0.25$ & $6.58 \pm 0.40$ & $6.62 \pm 0.38$ & $5.07 \pm 0.43^{\circ}$ \\
\hline Cholesterol, mmol/L & $3.15 \pm 0.14$ & $5.75 \pm 0.24 * * *$ & $2.02 \pm 0.12$ & $4.74 \pm 0.18^{\circ 00}$ \\
\hline Total bilinubin, $\mu \mathrm{mol} / \mathrm{L}$ & $3.93 \pm 0.22$ & $5.06 \pm 0.19 * * *$ & $2.74 \pm 0.29$ & $5.60 \pm 0.31^{000}$ \\
\hline
\end{tabular}

Note: see Table 1.

Table 3

Changes in biochemical parameters of mineral metabolism in the serum of dogs with co-infection T. vulpis + T. canis $(\mathrm{x} \pm \mathrm{SE})$

\begin{tabular}{|c|c|c|c|c|}
\hline \multirow{2}{*}{ Indexes } & \multicolumn{2}{|c|}{ Young dogs (6-12 months) } & \multicolumn{2}{|c|}{ Adult dogs $(1.5-8.0$ years $)$} \\
\hline & healthy, $\mathrm{n}=15$ & infected, $\mathrm{n}=25$ & healthy, $\mathrm{n}=10$ & infected, $\mathrm{n}=20$ \\
\hline Sodium, $\mathrm{mmol} / \mathrm{L}$ & $149.0 \pm 4.5$ & $155.1 \pm 6.3$ & $147.5 \pm 5.8$ & $153.4 \pm 5.4$ \\
\hline Potassium, $\mathrm{mmol} / \mathrm{L}$ & $5.72 \pm 0.26$ & $5.61 \pm 0.24$ & $5.65 \pm 0.23$ & $5.77 \pm 0.25$ \\
\hline Calcium, $\mathrm{mmol} / \mathrm{L}$ & $2.82 \pm 0.12$ & $2.46 \pm 0.06^{*}$ & $2.53 \pm 0.10$ & $2.45 \pm 0.12$ \\
\hline Phosphorus, mmol/L & $2.49 \pm 0.10$ & $2.45 \pm 0.11$ & $1.62 \pm 0.06$ & $1.50 \pm 0.07$ \\
\hline Magnesium, $\mathrm{mmol} / \mathrm{L}$ & $0.96 \pm 0.04$ & $0.85 \pm 0.03 *$ & $1.08 \pm 0.05$ & $0.99 \pm 0.06$ \\
\hline Chlorine, $\mathrm{mmol} / \mathrm{L}$ & $107.8 \pm 3.79$ & $105.3 \pm 4.1$ & $102.2 \pm 4.5$ & $100.0 \pm 3.7$ \\
\hline
\end{tabular}

Note: see Table 1.

Table 4

Changes in biochemical parameters of enzyme metabolism in the serum of dogs with co-infection T. vulpis + T. canis $(\mathrm{x} \pm \mathrm{SE})$

\begin{tabular}{|c|c|c|c|c|}
\hline \multirow{2}{*}{ Indexes } & \multicolumn{2}{|c|}{ Young dogs (6-12 months) } & \multicolumn{2}{|c|}{ Adult dogs $(1.5-8.0$ years $)$} \\
\hline & healthy, $n=15$ & infected, $\mathrm{n}=25$ & healthy, $n=10$ & infected, $n=20$ \\
\hline ALT, U/L & $36.4 \pm 1.9$ & $117.5 \pm 5.1^{* * *}$ & $30.1 \pm 3.4$ & $153.4 \pm 7.0^{\circ 00}$ \\
\hline AST, U/L & $40.1 \pm 1.3$ & $80.2 \pm 3.7^{* * *}$ & $22.3 \pm 3.3$ & $106.0 \pm 5.1^{000}$ \\
\hline$\alpha$-amylase, $\mathrm{U} / \mathrm{L}$ & $898.8 \pm 18.4$ & $1529.3 \pm 66.4^{* * *}$ & $732.2 \pm 12.8$ & $949.2 \pm 41.5^{\circ 00}$ \\
\hline GGT, U/L & $6.32 \pm 0.23$ & $18.56 \pm 0.92 * * *$ & $9.29 \pm 0.33$ & $33.25 \pm 1.57^{000}$ \\
\hline $\mathrm{ALP}, \mathrm{U} / \mathrm{L}$ & $27.2 \pm 0.7$ & $115.3 \pm 4.5^{* * *}$ & $16.2 \pm 0.4$ & $96.2 \pm 6.0^{\circ 00}$ \\
\hline
\end{tabular}

Note: see Table 1.

Studying the pathogenesis of helminthiasis in general and nematodes in dogs in particular, scientists have concluded that these pathologies are accompanied by various changes in haematological parameters. Thus, a study of the blood of dogs subclinically affected by Ancylostoma spp. revealed a significant increase in the concentration of C-reactive protein and haptoglobin, a significant decrease in iron and albumin (Schmidt et al., 2016).

According to the results of a study of the blood of dogs affected by co-infections of nematodes in various combinations, the authors identified such pathologies as anaemia, increased ALT activity, while creatinine concentration and ALP activity did not change significantly (Rouf et al., 2017).

After studying the effect of co-infection with Dirofilaria immitis and Ancylostoma caninum and morphological parameters of dogs' blood, the researchers found a decrease in the number of erythrocytes, leukocytosis, increased lymphocytes, monocytes and eosinophils against a decrease in neutrophils (Kumar, 2021).

Experimental infestation of white mice, as a laboratory model, with a culture of mature eggs of $T$. canis, after 30 days was manifested by such changes as erythrocytopenia, hypo-haemoglobinemia, leukocytosis, eosinophilia, decreased concentration of total protein, especially albumin fraction, increase in the concentration of total bilirubin, as well as the activity of the enzymes ALT and AST (Bakhur et al., 2018).

The results obtained by us after the study of haematological parameters of dogs co-infected with $T$. vulpis $+T$. canis are both general for nematodes and specific (Table 1). Thus, anaemia (decrease in the number of erythrocytes, haemoglobin and $\mathrm{MCH}$ ), found in young dogs aged 6-12 months, should be explained by the nutritional effects of parasites and lack of nutrients in the body, as well as the toxic effects of nematode metabolites on erythropoiesis (Smith et al., 2005; da Silva et al., 2015). Disruption of oxygen transport to tissues and organs caused by such processes was manifested in a significant decrease in MCV and haematocrit. The classic deviations for helminthiases were an increase in the number of leukocytes in young dogs and a sharp increase in the content of eosinophils in animals of both ages. These changes in the morphological parameters of the blood indicate an inflammatory process in patients and the immunological response to the sensitizing factor - metabolites and somatic substances of parasites (Shamsi et al., 2018; Miglio et al., 2020). However, the appearance of basophils in young and severe basophilia in adult dogs was specific, which may be justified by chronic inflammatory condition of the gastrointestinal tract (due to mechanical intervention of adult nematodes in the intestinal wall) and the same allergic reactions to helminths (Reck et al., 2011; Abbott \& Allen, 2020).

As can be seen from the results of the study of nutrient metabolism in the serum of dogs with co-infection with T. vulpis $+T$. canis (Table 2), the infection did not have a significant effect on hydrocarbon metabolism. But the metabolism of protein (and its fractions), as well as fats, has undergone significant changes, which, in turn, differed significantly between the age groups of the studied animals. Thus, a probable decrease in total protein concentration in young dogs and albumin content in both age groups indicate both protein deficiency and liver dysfunction (Zheng et al., 2021). Such a nutritional deficiency can be the result not only of protein deficiency in the diet but also, to a greater extent, impaired digestion and absorption of nutrients due to mechanical, trophic and toxic effects of parasites. The same types of negative effects of parasites on the body of the host can explain liver dysfunction (Cavalcanti et al., 2019), which is also confirmed by a significant increase in cholesterol and total bilirubin in the serum of dogs of both experimental age groups.

Also, a pronounced change in the serum biochemical parameters of infected dogs was an increase in the content of globulins $\alpha-1, \alpha-2$ and $\beta$ fractions, which are essential proteins of the so-called "acute phase" (Tothova et al., 2019). Such changes characterize the body's fight against foreign agents in response to infection. Serum creatinine concentrations in infected dogs of both ages, as well as urea in young dogs, did not differ 
significantly from those in healthy animals. However, the results obtained on these indicators differed significantly in individual animals within groups, which indicates different individual reactions of the organism to toxins of parasites T. vulpis and T. canis. The result of the study of the concentration of urea in the serum of infected adult dogs, which was significantly lower than in healthy animals, was special. This phenomenon can be explained by the alimentary depletion of animals and severe liver pathology (Pizzinatto et al., 2019).

The decrease in the concentration of calcium and magnesium in the serum of young dogs (Table 3 ) was probably due to a nutritional deficiency of these trace elements in the body due to disruption of digestion and absorption of nutrients as a result of parasitism of adult nematodes in the intestine (Smith et al., 2005; Sweeny et al., 2021). Perhaps a deficiency of these micronutrients is one of the factors in the chain of the pathogenesis of seizures in puppies with a high intensity of gastrointestinal parasite infection (Ryan, 2020). The absence of changes in the concentration of other macro-, and micronutrients in the serum of dogs with co-infection with $T$. vulpis $+T$. canis indicates the preservation of the functioning of the osmoregulatory system.

The most pronounced were the changes in the activity of the enzymes ALT, AST, $\alpha$-amylase, GGT, and ALP, which were significantly higher in infected dogs of both ages. Significantly higher intensity of increase in ALT activity in comparison with AST, as well as other changes in enzyme activity, indicate the hepatic origin of the pathology (Kaushik et al., 1997; Mazaro et al., 2019). Significant increase in $\alpha$-amylase activity in the serum of young dogs, much higher than in adult animals may be due to the possibility of parasitism of $T$. canis in the ducts of the pancreas and in the gland itself at a high intensity of infection with a significant number of adult nematodes (Miller, 2020). This is exactly the situation we observed in the group of young experimental dogs, as described above.

Significantly sharper changes in morphological and trophic blood parameters in young dogs, and metabolism in adults, should be explained by sensitivity to nutrient deficiencies in the former and age-related accumulation of chronic pathologies of vital organs in the latter.

\section{Conclusions}

According to the results of our parasitological study of dogs, it was found that the intensity of $T$. vulpis nematode infection among adult dogs (1.5-8.0 years) was 5.37 times higher than among young dogs (6-12 months). The intensity of $T$. canis infection, in contrast, was 2.58 times higher in young dogs than in adults.

Co-infection of $T$. vulpis $+T$. canis nematodes in young dogs showed signs of anaemia (erythrocytopenia, haemoglobinemia, decreased MCV and $\mathrm{MCH}$, haematocrit), inflammation and hyperimmune reactions (leukocytosis, basophilia and eosinophilia, increased $\alpha-1, \alpha-2$ and $\beta$-globulins), nutritional deficiency of protein and minerals (proteinemia, albuminemia, calcium and magnesium), liver dysfunction (increased cholesterol and total bilirubin, increased activity of ALT, AST, $\alpha$-amylase, GGT and ALP).

According to the results of a haematological examination of adult dogs infected with $T$. vulpis $+T$. canis, there were signs of moderate sensitization and hyperimmune reaction (eosinophilia and basophilia, increased levels of $\alpha-1, \alpha-2$ and $\beta$-globulins), profound liver dysfunction (albuminemia, increased cholesterol and total bilinubin, decreased urea, increased activity of enzymes ALT, AST, $\alpha$-amylase, GGT and ALP).

Thus, co-infection with nematodes $T$. vulpis $+T$. canis has a complex pathogenic effect, which involves vital organs and body systems of dogs of all ages.

The current studies are the initiative of the authors and do not have any outside financial support. The research was carried out within the framework of the initiative topic for scientific work "Development of schemes for antiparasitic treatments of animals and methods for evaluating their effectiveness" (state registration No. 0116U005326).

The authors are grateful to the leaders of the Homeless Animal Welfare Center "In Good Hands" - director Kateryna Zhukovska and veterinarian Stanislav Yeremeychuk for their help and assistance in conducting research, as well as for their important work in helping homeless animals.

\section{References}

Abbott, D. E. E., \& Allen, A. L. (2020). Canine eosinophilic pulmonary granulomatosis: Case report and literature review. Journal of Veterinary Diagnostic Investigation, 32(2), 329-335.

Abou-El-Naga, I. F. (2018). Developmental stages and viability of Toxocara canis eggs outside the host. Biomedica, 38(2), 189-197.

Bakhur, T., Holovakha, V., \& Antipov, A. (2018). Visceral toxocarosis in the model of white mice: Effect on the body. In: Prokes, M. (Eds.). Infectious and parasitic diseases of animals: 6th International Scientific Conference. UVLF, Košice. Pp. 47-50.

Bindke, J. D., Springer, A., Janecek-Erfurth, E., Boer, M., \& Strube, C. (2019). Helminth infections of wild European gray wolves (Canis lupus Linnaeus, 1758) in Lower Saxony, Germany, and comparison to captive wolves. Parasitology Research, 118(2), 701-706.

Bojar, H., \& Klapec, T. (2018). Contamination of selected recreational areas in Lublin Province, Eastern Poland, by eggs of Toxocara spp., Ancylostoma spp. and Trichuris spp. Annals of Agricultural and Environmental Medicine, 25(3), $460-463$.

Borodai, Y. O., \& Hodyna, V. P. (2019). Poshyrennia ta osoblyvosti perebihu trykhurozu sobak na terytorii mista Poltava [Distribution and features of dog trichurosis in Poltava city]. Bulletin of Poltava State Agrarian Academy, 3, 200-206 (in Ukrainian).

Boyko, A. A., \& Brygadyrenko, V. V. (2017). Changes in the viability of Strongyloides ransomi larvae (Nematoda, Rhabditida) under the influence of synthetic flavourings. Regulatory Mechanisms in Biosystems, 8(1), 36-40.

Cavalcanti, E. B. D., Baioto, G. C., Marcolongo-Pereira, C., de Souza, M. C. C., Rassele, A. C., \& Horta, R. D. (2019). Congenital extrahepatic portosystemic deviation in a mixed-breed dog. Acta Scientiae Veterinariae, 47, 362.

da Silva, P. H., Laposy, C. B., Giuffrida, R., Chaves, M. P., \& de Freitas, M. W. (2015). Relationship between the red blood cell distribution width (RDW) and erythrocyte values in anemic and non-anemic cats. Semina-Ciencias Agrarias, 36(5), 3227-3232.

Duncan, K. T., Koons, N. R., Litherland, M. A., Little, S. E., \& Nagamori, Y. (2020). Prevalence of intestinal parasites in fecal samples and estimation of parasite contamination from dog parks in Central Oklahoma. Veterinary Parasitology - Regional Studies and Reports, 19, 100362.

Feshchenko, D. V., Bakhur, T. I., Selcuk, B. H., Antipov, A. A., Zghozinska, O. A., Dubova, O. A., Yevstafyeva, V. O., Goncharenko, V. P., Shahanenko, R. V., Shahanenko, V. S., \& Melnychuk, V. V. (2019). Mollusks (Gastropoda) as intermediate hosts of cattles' trematodes (Trematoda) in conditions of Dnipro basin's small ponds (Northern Ukraine). Acta Veterinaria Eurasia, 45(1), 16-21.

Gebremedhin, E. Z., Tola, G. K., Sarba, E. J., Getaneh, A. M., Marami, L. M., \& Endale, S. S. (2020). Prevalence and risk factors of helminths' infection of dogs in three towns of west Shoa zone, Oromia regional state, Ethiopia. Veterinary Parasitology - Regional Studies and Reports, 21, 100443.

Iliev, P. T., Kirkova, Z. T., \& Tonev, A. S. (2020). Preliminary study on the prevalence of endoparasite infections and vector-borne diseases in outdoor dogs in Bulgaria. Helminthologia, 57(2), 171-178.

Kaushik, S. P., Hurwitz, M., McDonald, C., \& Pavli, P. (1997). Toxocara canis infection and granulomatous hepatitis. American Joumal of Gastroenterology, 92(7), 1223-1225.

Kumar, A. (2021). Haematological alterations during concurrent infection of Dirofilaria immitis and Ancylostoma caninum infections in dog and its therapeutic management: A case report. Journal of Entomology and Zoology Studies, 9(2), 185-186.

La Torre, F., Di Cesare, A., Simonato, G., Cassini, R., Traversa, D., \& di Regalbono, A. F. (2018). Prevalence of zoonotic helminths in Italian house dogs. Journal of Infection in Developing Countries, 12(8), 666-672.

Marko, R., Sanda, D., Aleksandar, V., Danica, B., Bojan, G., Miodrag, S., \& Tamara, I. (2020). Dogs from public city parks as a potential source of pollution of the environment and risk factor for human health. Indian Joumal of Animal Sciences, 90(4), 535-542.

Mazaro, R. D., da Luz, F. S., Herbichi, A. P., Paz, M. C., \& Fighera, R. A. (2019). Hemolytic crisis in a dog with copper-associated chronic hepatitis. Acta Scientiae Veterinariae, 47, 472.

Medina-Pinto, R. A., Rodriguez-Vivas, R. I., \& Bolio-Gonzalez, M. E. (2018). Zoonotic intestinal nematodes in dogs from public parks in Yucatan, Mexico. Biomedica, 38(1), 105-110.

Melnychuk, V., Yevstafieva, V., Bakhur, T., Antipov, A., \& Feshchenko, D. (2020). prevalence of gastrointestinal nematodes in sheep (Ovis aries) in the central and south-eastem regions of Ukraine. Turkish Joumal of Veterinary and Animal Sciences, 44(5), 985-993.

Miglio, A., Gavazza, A., Siepi, D., Bagaglia, F., Misia, A., \& Antognoni, M. T. (2020). Hematological and biochemical reference intervals for 5 adult hunting dog breeds using a blood donor database. Animals, 10(7), 1212. 
Miller, A. D. (2020). Pathology of larvae and adults in dogs and cats. Toxocara and Toxocariasis, 109, 537-544.

Mohaghegh, M. A., Vafaei, M. R., Ghomashlooyan, M., Azami, M., Falahati, M., Azadi, Y., Yousefi, H. A., Jabalameli, Z., \& Hejazi, S. H. (2018). A wide diversity of zoonotic intestinal parasites in domestic and stray dogs in rural areas of Kermanshah province, Iran. Tropical Biomedicine, 35(1), 82-90.

Motta, C. E., Rivero, M. R., De Angelo, C. D., Sbaffo, A. M., \& Tiranti, K. I. (2019). Risk and protective factors associated with gastrointestinal parasites of dogs from an urban area of Cordoba, Argentina. Turkish Joumal of Veterinary and Animal Sciences, 43(6), 846-851.

Pizzinatto, F. D., Freschi, N., Sonego, D. A., Stocco, M. B., Dower, N. M. B., Martini, A. D., \& de Souza, R. L. (2019). Parasitism by Dioctophyma renale in a dog: Clinical and surgical aspects. Acta Scientiae Veterinariae, 47, 407.

Reck, J., Soares, J. F., Termignoni, C., Labruna, M. B., \& Martins, J. R. (2011). Tick toxicosis in a dog bitten by Ornithodoros brasiliensis. Veterinary Clinical Pathology, 40(3), 356-360.

Ristic, M., Miladinovic-Tasic, N., Dimitrijevic, S., Nenadovic, K., Bogunovic, D., Stepanovic, P., \& Ilic, T. (2020). Soil and sand contamination with canine intestinal parasite eggs as a risk factor for human health in public parks in Nis (Serbia). Helminthologia, 57(2), 109-119.

Rouf, A., Khurana, K., Dar, S., Shah, O., Rather, M., \& Khaliq, T. (2017). Prevalence and haemato-biochemical alterations in GI helminth infected dogs from Bareilly, India. International Journal of Livestock Research, 7(7), 166-170.

Ryan, E. T. (2020). Toxocariasis. In: Ryan, E. T., Solomon, T., Endy, T. P., Hill, D. R., Aronson, N. E. (Eds.). Hunter's tropical medicine and emerging infectious diseases. Elsevier. Pp. 885-887.

Saichenko, I. V., \& Antipov, A. A. (2020). Epizootychna sytuatsiia shchodo nematodoziv shlunkovo-kyshkovoho kanalu sobak [Epizootic situation regarding nematodes of the gastrointestinal tract of dogs]. Scientific Joumal of Veterinary Medicine, 1, 54-62 (in Ukrainian).

Savilla, T. M., Joy, J. E., May, J. D., \& Somerville, C. C. (2011). Prevalence of dog intestinal nematode parasites in south central West Virginia, USA. Veterinary Parasitology, 178, 115-120.

Scaramozzino, P., Carvelli, A., Iacoponi, F., \& De Liberato, C. (2018). Endoparasites in household and shelter dogs from Central Italy. International Joumal of Veterinary Science and Medicine, 6(1), 45-47.
Schmidt, E. M. S., Tvarijonaviciute, A., Martinez-Subiela, S., Ceron, J. J., \& Eckersall, P. D. (2016). Changes in biochemical analytes in female dogs with subclinical Ancylostoma spp. infection. BMC Veterinary Research, 12, 203.

Shamsi, S., Loukopoulos, P., McSpadden, K., Baker, S., \& Jenkins, D. (2018). Preliminary report of histopathology associated with infection with tongue worms in Australian dogs and cattle. Parasitology International, 67(5), 597-600.

Smith, V. H., Jones, T. P., \& Smith, M. S. (2005). Host nutrition and infectious disease: An ecological view. Frontiers in Ecology and the Environment, 3(5), 268-274.

Stafford, K., Kollasch, T. M., Duncan, K. T., Horr, S., Goddu, T., Heinz-Loomer, C., Rumschlag, A. J., Ryan, W. G., Sweet, S., \& Little, S. E. (2020). Detection of gastrointestinal parasitism at recreational canine sites in the USA: The DOGPARCS study. Parasites and Vectors, 13(1), 275.

Sweeny, A. R., Clerc, M., Pontifes, P. A., Venkatesan, S., Babayan, S. A., \& Pedersen, A. B. (2021). Supplemented nutrition decreases helminth burden and increases drug efficacy in a natural host-helminth system. Proceedings of the Royal Society B, 288(1943), 20202722.

Symeonidou, I., Gelasakis, A. I., Arsenopoulos, K. V., Schaper, R., \& Papadopoulos, E. (2017). Regression models to assess the risk factors of canine gastrointestinal parasitism. Veterinary Parasitology, 248, 54-61.

Tothova, C., Lukac, B., Kadasi, M., Baranova, D., Weissova, T., \& Nagy, O. (2019). The electrophoretic pattern of serum proteins in dogs with babesiosis. Acta Veterinaria Brno, 88(4), 425-432.

Yevstafieva, V., Horb, K., Melnychuk, V., Bakhur, T., \& Feshchenko, D. (2020). Ectoparasites Ctenocephalides (Siphonaptera, Pulicidae) in the composition of mixed infestations in domestic dogs from Poltava, Ukraine. Folia Veterinaria, 64(3), 47-53.

Yong, T. S., Lee, K. J., Shin, M. H., Yu, H. S., Suvonkulov, U., Sergeevich, T. B., Shamsiev, A., \& Park, G. M. (2019). Prevalence of intestinal helminth infections in dogs and two species of wild animals from Samarkand Region of Uzbekistan. Korean Joumal of Parasitology, 57(5), 549-552.

Zazharska, N., Boyko, O., \& Brygadyrenko, V. (2018). Influence of diet on the productivity and characteristics of goat milk. Indian Journal of Animal Research, 52(5), 711-717.

Zheng, W. B., Zou, Y., He, J. J., Liu, G. H., Hu, M. H., \& Zhu, X. Q. (2021). Proteomic alterations in the plasma of Beagle dogs induced by Toxocara canis infection. Journal of Proteomics, 232, 104049. 